\title{
Na cestě ke společnosti světoobčanư? Nevládní organizace, sociální hnutí a „noví" aktivisté vně státních hranic
}

\author{
Ondřej Císař
}

Práva člověka byla ostatně definována jako „,nezcizitelná“ proto, že se předpokládalo, že budou nezávislá na všech vládách; ukázalo se však, že v okamžiku, kdy lidské bytosti neměly vlastní vládu a musely se uchýlit ke svým minimálním právům, nebyla zde k ochraně těchto práv žádná autorita a žádná instituce nebyla ochotna se za ně zaručit.

(Arendtová 1996: 411)

\section{Úvod}

Kontury moderní demokracie, demokratického občanství i jeho infrastruktury - občanské společnosti - se dnes v důsledku vnitřní společenské pluralizace a vnější globalizace viditelně proměňují. Tato stat' se zaměří na některé důležité konsekvence, které výkonu politických práv přinesl druhý zmíněný proces - globalizace, respektive politická internacionalizace (k vymezení rozdílu mezi globalizací a internacionalizací srov. Tarrow 2002, Císař 2004: kap. 2). Primárně přitom bude zkoumat proměnu organizační a komunikační infrastruktury občanské společnosti, kterou vytvářejí formální i neformální sítě sociálních hnutí, občanských sdružení, nevládních organizací i individuálních aktivistů.

Podle klasické Marshallovy formulace se od 18. do 20. století postupně etablovala občanská, politická a následně sociální práva (Marshall a Bottomore 1992: 8-17). Společně s rozšiřováním typů práv se také rozšiřovala samotná skupina občanů - původně vyloučené skupiny byly zahrnovány do občanského tělesa tvořícího dané společenství. Konečné hranice tohoto společenství však byly pevně dány - byly to hranice národního státu, v jehož rámci existoval pocit sdílené sounáležitosti a př́slušnosti $\mathrm{k}$ jednomu celku. Jinými slovy, rozvoj institucí a procedur liberální demokracie předpokládal existenci národní komunity jako sdíleného prostředí občanství. Podle některých současných reflexí však takové komunitární chápání demokracie jen stěží poskytuje adekvátní nástroje pro to, abychom se mohli vypořádat se změnami, které jsou charakterizovány postupující decentrací a rozpouštěním národních komunit a identit v důsledku vnějších tlaků ekonomické a kulturní globalizace. Podle tohoto názoru nadešel čas k tomu, aby v důsledku postupujících globalizačních procesů začala teorie demokracie brát vážně možnosti demokratizace na nadnárodní úrovni. Cílem těchto požadavků je rozvinout koncepci

Sociální studia. Fakulta sociálních studií Masarykovy univerzity v Brně, 1/2005. S. 87-109. ISSN 1214-813X. Tato staf byla zpracována v rámci projektu „Politická teorie sociálních hnutí“. Projekt je realizován za finanční podpory ze státních prostředkủ prostřednictvím Grantové agentury České republiky (reg. číslo 407/05/P051). 
(národního) občanství do globálního demokratického občanství a demokratizovat existující mezinárodní institucionální uspořádání. Nositelem demokratizace na nadnárodní úrovni má být globální občanská společnost.

V této stati podrobíme údajný demokratizační potenciál globální občanské společnosti kritickému posouzení a př́ípadné reinterpretaci. K tomu je nejprve třeba definovat postavení pojmu globální občanské společnosti v rámci studia globalizace. Následně budou vymezeny tři pozice (resp. tradice) v současné diskusi o možnostech realizace demokracie na nadnárodní úrovni. V rámci každé tradice bude definována funkce, kterou podle ní plní občanská společnost. Další sekce se obrátí k empiricky orientované analýze. Podle převládající interpretace je globální občanská společnost tvořena různými mezinárodními nevládními organizacemi a sociálními hnutími. Stat' proto nejprve shrnuje data popisující tento typ politických aktérů a dále se zaměřuje na „nový“ typ globálního (individualizovaného) aktivismu. V další sekci diskutuje dopad, který by aktivity studovaných organizací a hnutí mohly mít na realizaci demokratické kontroly na nadnárodní úrovni. Na tuto část navazuje expozice skeptického pohledu na možnost uskutečnění globálního demokratického občanství. Občanství je odlišeno od aktivismu a jsou diskutovány problémy, s nimiž se současný globální politický aktivismus potýká. V závěru stati je posouzen demokratizační potenciál „globální občanské společnosti“: její aktéŕi sice mohou zasáhnout do politické komunikace a přispět ke zvýšení transparentnosti politického rozhodování na globální úrovni, nejsou však nositeli globálního občanství. Na globální úrovni kategorie demokratického občanství chybí, je naopak zajišt'ována institucemi (demokratických) států. Samotná existence globální občanské společnosti je proto závislá na politických a ekonomických podmínkách v jednotlivých státech. S tím souvisí také to, že by se její aktivity namísto nerealizovatelného projektu globální demokracie měly spíše zaměřit na posilování občanské autonomie na úrovni jednotlivých států. ${ }^{1}$

\section{Tři pojetí globalizace}

Diskuse o existenci či neexistenci struktur občanské společnosti na nadnárodní úrovni se rozpoutala relativně nedávno (viz např́klad Habermas 1998d, Florini 2000, Anheimer et al. 2001, Halliday 2001, Rucht 2001, Klein 2001, Hardt 2002, Ancelovici 2002, Graeber 2002, Císař 2003c, Keane 2003, Barša a Císař 2004, della Porta a Tarrow 2005). V souvislosti s rostoucí globalizací ekonomické a kulturní výměny se pozornost řady teoretiků a píśících aktivistů obrátila k faktu mohutnějící prítomnosti rozličných občanských sdružení, nevládních organizací a sociálních hnutí na nadnárodní úrovni. Globalizace podle těchto výkladů neprobíhá jen ve smyslu ekonomickém či kulturním, ale také politickém. A právě rostoucí počet transnacionálních občanských iniciativ je chápán jako jeden z prominentních projevů politické globalizace. Tato občansko-politická globalizace je navíc některými autory kladena jako alternativní reprezentace $\mathrm{k}$ převládajícím výkladům současných politických a sociálně-ekonomických proměn na globální úrovni (následující výklad tří pozic volně sleduje McGrew 2000).

Podle marxistické interpretace jsou v globalizovaném světě všechny státy podřizeny tlaku kapitálu. (To se týká také jediné současné velmoci - USA.) Zatímco v poválečném období se (alespoň v rámci průmyslově vyspělého světa) podařilo tržní síly spoutat nástroji keynesiánského řízení ekonomiky, dnešní globalizace dává kapitálu volnou ruku a podřizu- 
je stát jeho diktátu. Podle principů neoliberální ideologie tak dochází k celkovému podřízení sociálních vztahů imperativům trhu. Stát, který do 70 . let 20. století sloužil jako „obranný val“ před výkyvy hospodářského cyklu, se přeměnil na ,převodový řemen“, který přenáší tlak globálního kapitalismu do národních společností (Cox 1996). Vše je tak ovládáno imperativem zisku a transnacionálními korporacemi, globální kapitalistickou tř́́dou a jejími přisluhovači (mezinárodními finančními institucemi - Mezinárodním měnovým fondem, Světovou bankou - i Evropskou unií [EU] (viz Gill 1995, Sklair 1997, van Apeldoorn 2000).

Podle realistů naopak na globální úrovni nerozhoduje ekonomická, ale vojenská moc. Ta je dnes koncentrována v rukou jediné velmoci, která přežila studenou válku - USA (Waltz 1999). To, že jsou Spojené státy světovou velmocí, neznamená, že by přímo určovaly politiku ostatních zemí. Jak jsme ale viděli na př́kladu irácké invaze (2003), jsou schopny obejít existující multilaterální instituce a jednat unilaterálně. Tento pohled globalizaci slučuje s amerikanizací a vidí ji jako produkt liberálního světového rádu vnuceného po 2 . Světové válce ostatnímu světu Spojenými státy. Obrat americké zahraniční politiky po 11. Září 2001 je pak automaticky interpretován jako proměna celkového mezinárodního uspořádání - jako posun od liberálních pravidel k politice moci (Barša 2003). Realistická očekávání se zdají být opět potvrzena politickou praxí. Zatímco v 90 . letech 20. století se (evropští) liberálové mohli oddávat kantovskému snění, nové tisíciletí potvrdilo, že člověk je veskrze špatná bytost, s níž nemá smysl debatovat, ale kterou je třeba podřídit mocenskému dohledu (pro takový pohled viz Kagan 2003).

Omezenost tohoto pohledu dokládá nejen nedostatek efektivity jednostranně vojenských řešení při zajištování globální bezpečnosti ve světě ohrožovaném teroristickými sítěmi, ale také hlasité vystoupení kritického „globálního veřejného míněni“ $v$ p podobě protiválečných protestů $\mathrm{v}$ roce 2003. Tyto protesty navazovaly na podobné události, v jejichž rámci v 90 . letech vstupovaly do mezinárodně-politického prostoru nikoli pouze státy či ekonomické korporace, ale i sdružení občanů (srov. Kaldor et al. 2003: 24). Tato (v našem výkladu třetí) pozice tak namísto ekonomických (marxisté) či politických (realisté) struktur zdůrazňuje globální význam jednání individuálních aktérů sdružených v nevládních organizacích, sociálních hnutích a komunikačnich sitích. Tato sdružení v 90 . letech protestovala (často úspěšně) proti ekonomické globalizaci a dnes se obracejí proti globalizaci militární (tamtéž). Jejich existence má přitom být důkazem toho, že tocquevilleovská občanská společnost aktivně participujících jedinců se neformuje jen na úrovni států, ale také za jejich hranicemi (srov. Barša a Císař 2004).

Podle optimistických předpovědí by vstup „občanské společnosti“ na globální úroveň mohl vést $k$ podřízení mezinárodně-politických rozhodnutí veřejné kontrole. $V$ tomto smyslu by se na globální úrovni opakoval scénář, který charakterizoval vývoj moderního liberálního státu a v jeho rámci fungujícího demokratického procesu. To by mohlo platit i přes to, že globální občanská společnost se diametrálně liší od občanské společnosti fungující v rámci jednoho státního útvaru. Skeptické hlasy však zdůrazňují, že se moderní občanská společnost vyvíjela společně s moderním státem, a proto o ní nelze bez existence „světového státu“ na globální úrovni mluvit.

Jak však upozorňují jiné pokusy o promýšlení pojmu občanské společnosti, historická tradice této ideje sahá dále než $\mathrm{k}$ hegelovskému pojetí, které ji skutečně pevně usadilo, i když jako distinktivní kategorii, do rámce státu jako realizovaného rozumu. Předhegelovská tradi- 
ce myšlení o občanské společnosti sahající k myslitelům skotského osvícenství (Hume, Smith, Ferguson) ji spíše chápe jako zvláštní typ sociability a spolu s tím akcentuje politickou participaci a občanské ctnosti jako nutný korektiv k individualizujícím silám tehdy se rozvíjejícího trhu (Oz-Salzberg 2001). Analogicky k představě Adama Fergusona o korekci tržního individualismu 18. století by pak mohla být globální občanská společnost přijata jako „civilizační“ síla globalizujícího se kapitalismu a jednostranného militarismu (Held 2004). Jinými slovy řečeno, mohla by se stát nositelem demokratizace světového politického a ekonomického řádu. Konkrétní role, kterou občanská společnost v tomto smyslu může sehrát, se však bude lišit v závislosti na perspektivě, z níž na nadnárodní demokracii nahlížíme.

\section{Občanská společnost a demokracie: participace, transparentnost, nebo komunikace?}

Ve svém silném (radikálním) významu má občanská společnost prorazit omezení národních politických jednotek a vytvořit podmínky pro realizaci kontroly politické a ekonomické moci na nadnárodní úrovni. Podobně jako pluralita sociálních zájmů, která se v průběhu posledních tř́i staletí vyrýsovala na půdorysu moderní (národní) společnosti, zpochybnila domněle přirozené postavení dědičného monarchy, má dnešní (globální) pluralita zatrást domněle přirozeným postavením postindustriální ekonomicko-politické elity (srov. Barša a Císař 2004).

Existující mezinárodní uspořádání pro zastánce radikálního pohledu ztělesňuje zájmy bohaté a mocné globální elity. Proto nejde o jeho „kosmetickou“ reformu, ale o vytvoření podmínek pro kvalitativně odlišnou globální politiku. Ta by nebyla navázána na vyspělými zeměmi ovládané mezinárodní organizace, ale mírila by na radikálně reformní projekt „nové politiky“ $\mathrm{s}$ cílem restrukturalizovat existující globální struktury zdola (Brecher et al. 2000, Hardt a Negri 2000, Klein 2001, Hardt 2002, Graeber 2002). Globální radikální demokraté proto vkládají naději do transnacionálních občanských hnutí (formujících širší hnutí za globální sociální spravedlnost), která se snaží vůči ekonomické globalizaci postavit její občanskou alternativu. Ta jako jediná podle těchto hlasů ztělesňuje potenciál spravedlivějšího světového rádu.

Tato pozice navazuje na dřívější radikální politiku nových sociálních hnutí na národní úrovni, kterým šlo o prohloubení demokracie i ve dříve „,nepolitických“ oblastech (viz Barša a Císař 2004). Podobně jako se feministické hnutí snažilo podř́dit demokratickému vyjednávání rodinné vztahy, snaží se dnes hnutí za globální sociální spravedlnost podřídit demokratické kontrole světový obchod a rozvojovou politiku. Stejně jako feministky i alterglobalisté tak vynášejí demokratickou praxi vně úzce vymezený prostor liberálního státu.

Podle této pozice se možnosti demokratické participace nevyčerpávají v institucích národní reprezentativní demokracie. Naopak - „,některé elementy př́tomné v demokratickém étosu mohou sahat za hradby státu“ (Connolly 1991: 478). Aktéry, kteř́ by mohli být nositeli takového demokratického étosu, jsou právě sociální hnutí přesahující svou činností státní hranice a zpochybňující exkluzivitu státní suverenity. Sociální hnutí takto šírí demokratickou praxi vně domácí komunity. R. B. J. Walker zdůrazňuje, že „praktiky sociálních hnutí ne vždy odpovídají kódům vnitřku a vnějšku, představě časoprostorových vztahů formujících normativní horizont moderní politiky“ (Walker 1994: 672). Sociální hnutí tak nejen vynášejí demo- 
kratickou praxi z uzavřených národních společenství, ale pomáhají rozbíjet sterilní mentální mapu moderní politiky, čímž otevírají cestu k nastolení participačních mechanismů nutných pro zvládání problémů globalizovaného světa. Tato pozice tak v rámci rodící se teorie transnacionální demokracie nejvýraznějším způsobem rozvíjí rousseauovské radikálně demokratické dědictví. Nejedná se však o jediný možný pohled na demokratizační potenciál občanské společnosti na nadnárodní úrovni.

Radikálně demokratický pluralismus vyžaduje pro realizaci svých představ zcela novou organizaci mezinárodních vztahů. Proto působí vzhledem k existujícím mechanismům subverzivně (McGrew 2002: 219). V tom se odlišuje od druhé distinktivní pozice - liberálního internacionalismu, který se nesnaží o realizaci radikálně demokratické vize přímé občanské participace, ale hodlá dále rozvíjet existující mechanismy a pravidla liberální demokracie také na mezinárodní úrovni (např́klad Nye 2001, Keohane a Nye 2000, Keohane 2002). V porovnání s radikálními demokraty je liberální agenda minimalistická. Liberálům jde ve skutečnosti jen o zvýšení transparentnosti rozhodování hlavních mezinárodních organizací. V tomto projektu mají sehrát svou roli i organizace transnacionální občanské společnosti, které díky svému zapojení do mezinárodních politických struktur (Evropská unie, Mezinárodní měnový fond, Světová obchodní organizace) mohou zvýšit transparentnost jejich fungování a tím dosáhnout zvýšení odpovědnosti (accountability) politických elit (Nye 2001, Keohane 2002). Tato pozice tak promýšlí způsoby aplikace procedur liberální demokracie na nadnárodní úrovni. Podle kritiků jde o technokratický pohled, který podstatu demokratické politiky redukuje na soubor technických pravidel (Mayall 2000: 74). Demokracie není podle těchto kritických hlasů jen otázkou správných institucí a pravidel, ale také participujících občanů, kteří jsou schopni činit odpovědné volby.

Tuto výhradu samozřejmě vznášejí radikální demokraté. Vedle nich na tuto kritiku odpovídají také koncepce deliberativní demokracie, které spojují liberální důraz na nestranná pravidla s radikálně demokratickým důrazem na politickou participaci. Na rozdíl od liberálních internacionalistů tak deliberativistům nejde jen o nalezení těch správných institucí globální vlády, ale o otevření možností pro transnacionální veřejnou sféru, která by mohla zprostředkovávat skutečnou debatu mezi relevantními politickými aktéry - nositeli moci a těmi, kteří je chtějí dostat pod demokratickou kontrolu (Dryzek 1999). Cílem je poskytnutí podmínek pro veřejnou debatu - deliberaci - mezi všemi složkami globální politické sféry. Takto vymezená demokracie by neměla být založena na fixně definovaných kolektivech, jakými jsou např́klad národní státy, ale měla by si flexibilně tvořit deliberativní tělesa na základě projednávaného problému tak, aby byly do rozpravy vždy zahrnuty všechny zainteresované strany a aby tyto mohly vyjádřit svůj názor bez ohledu na svou národní př́slušnost (Thompson 1999). Taková koncepce podle svých obhájců poskytuje unikátní př́ležitost pro globalizovaný svět, v němž se rozpouštějí všechny původně stabilní kolektivity (Dryzek 1999). Aplikací tohoto principu budou deliberativní komunity jednoduše tvořeny podle požadavků konkrétního problému.

Deliberativní demokracie je však zř́dka chápána jako všezahrnující model uspořádání. Spíše se hovoří o aplikaci jejích aspektů $\mathrm{v}$ rámci garantovaných ústavních práv na národní a existujících procedur politického rozhodování na mezinárodní úrovni. V tomto světle je třeba chápat Habermasův (1998a) návrh na posílení participace nevládních organizací při jednáních mezinárodních organizací; tato participace by podle něj dokázala propojit dnes tak vzdálená jed- 
nání globální politické elity s národními veřejnými sférami. Pokud by navíc OSN mohla požadovat, aby státy ve sporných př́padech vypisovaly referenda, přispělo by to podle Habermase k debatě dnes přehlížených globálních problémů národními veřejnostmi bez nutnosti ustavovat globální politickou autoritu (Habermas 1998a, 1998b). Otevřené prostory pro deliberaci by tak daly možnost realizaci „světové domácí politiky“, která je podle Habermase nutným předpokladem zvládání globálních výzev ve světě, v němž chybí a bude chybět jednotné politické centrum. Jinými slovy řečeno, jen otevřené vertikální kanály by umožnily komunikovat o globálních problémech i ve světě států. Tři výše představené perspektivy shrnuje následující tabulka (srov. také McGrew 2002, Habermas 2002, Císař 2003b, Císař 2005).

Tabulka 1: Modely demokracie a role občanské společnosti (OS)

\begin{tabular}{|c|c|c|c|}
\hline & \multicolumn{2}{|c|}{ důraz na pravidla } \\
\hline & & ano & ne \\
\hline \multirow{2}{*}{$\begin{array}{r}\text { dưraz na } \\
\text { participaci }\end{array}$} & ano & $\begin{array}{l}\text { deliberativní model (Habermas), role OS: } \\
\text { zajištění komunikace }\end{array}$ & $\begin{array}{l}\text { radikálně demokratický model: } \\
\text { demokratický pluralismus (radikální kritika } \\
\text { globalizace), role OS: prímá participace }\end{array}$ \\
\hline & ne & $\begin{array}{l}\text { liberální model: liberální internacionalismus } \\
\text { (Keohane, Nye), role OS: zajištění } \\
\text { transparentnosti a accountability }\end{array}$ & - \\
\hline
\end{tabular}

Tabulka přehledným způsobem spojuje tři modely demokracie (liberální, radikální, deliberativní) s diskusí o politických konsekvencích současné globalizace. V liberálním chápání se hledání podmínek uskutečnění a udržení demokratické vlády kryje s hledáním takového institucionálního a procedurálního uspořádání, které by zajistilo férovou politickou soutěž mezi ve společnosti soupeřícími zájmy (viz např́iklad Shapiro 2002, 2003: 149-73). Politická participace $\mathrm{v}$ tomto pojetí má pouze instrumentální význam - je nástrojem pro řešení společenských a ekonomických problémů, které soukromí aktéři nejsou schopni vyřešit bez vzájemné kooperace. Podle tohoto modelu mají organizace občanské společnosti pomoci zajistit transparentnost systému politického rozhodování a nutit tak tř́́du profesionálních politikủ, aby se zodpovídala ze svých rozhodnutí. To se týká jak domácích, tak mezinárodních institucí.

V radikálním pojetí to naopak nejsou nestranná pravidla, která stanovují mantinely otevřené politické soutěži, ale tvorba společné vůle v rámci deliberace společenského celku, která dává demokracii její skutečný obsah. Zatímco liberální pojetí je založeno na individuální autonomii (člověk je svobodný tehdy, když je mu poskytnut prostor osobní svobody), radikální chápání stojí na koncepci veřejné autonomie (člověk je svobodný tehdy, když se může považovat nejen za př́ijemce, ale také autora zákonů, jimž se podřizuje). Radikální demokraté tak proti liberální svobodě od politiky staví důraz na svobodu jako participaci (srov. Císař 2003a). Zatímco „,[p]odle liberální varianty se občané státu v podstatě neliší od soukromých osob, které své předpolitické zájmy uplatňují vůči státnímu aparátu, podle [radikálně-demokratické] varianty se státní občanství aktualizuje jen v kolektivní praxi sebeurčování“ (Habermas 1996: 498, 2004: 191).

Jak již bylo řečeno, koncepce deliberativní demokracie pak inovativním způsobem spojuje liberální důraz na nestranná pravidla s radikálně-demokratickým zdůrazněním občanské deliberace: „V souladu s [radikálně-demokratickým pojetím] posouvá do centra pozornosti proces politického utváření mínění a vůle, aniž by však právní ustavení státu chápala jako 
něco druhotného; základní práva a principy právního státu chápe spíše jako důslednou odpověd’ na otázku, jak mohou být institucionalizovány náročné předpoklady komunikace demokratického procesu“ (Habermas 2002: 90). Deliberace však již nemá být realizována v celku občanského tělesa, ale $\mathrm{v}$ decentralizovaných strukturách občanské společnosti na všech úrovních politického rozhodování. Teorie deliberativní demokracie tak předpokládá rozšíření a pluralizaci platforem politické deliberace a otevření prostoru veřejné diskusi. Tím by se vytvořily podmínky pro to, aby mohlo dojít $\mathrm{k}$ propojení politické diskuse na různých úrovních politického procesu. Nás zde zajímá především komunikace mezi mezinárodní a domácí politikou. Jak jsme viděli výše, tu by v Habermasově (a nejen jeho) představě měly zajištovat právě sítě (globální) občanské společnosti přemost'ující dnešní propast mezi národními veřejnostmi a globální (respektive nadnárodní) politikou.

\section{Podoba globální občanské společnosti}

Co tedy globální občanská společnost označuje? Pro některé se zhmotňuje v ulicích měst, v nichž se odehrávají výroční zasedání Světové banky, Mezinárodního měnového fondu a Světové obchodní organizace či demonstrace proti vojenskému řešení současných globálních problémů. Pro další je ztělesněna pravidelnými interakcemi transnacionálních nevládních organizací, jakými jsou napríklad Amnesty International, Friends of the Earth International či Greenpeace (Císař 2004, Císař a Fiala 2004). Jiní ji zase chápou jako obecně rostoucí propojenost všech typů potenciálně politické činnosti, která díky rozvoji komunikačních technologií (především internetu) probíhá stále více přes státní hranice a stále méně skrze formalizované organizační struktury (Bennett 2005).

Když je třeba podložit argument o objevení se občanské společnosti na globální úrovni empirickými daty, hovoří se dosud nejčastěji o růstu počtu mezinárodních nevládních organizací (INGOs, international non-governmental organizations), paralelních summitů organizovaných odpůrci ekonomické globalizace a o rostoucím významu transnacionálních vazeb mezi rozličnými nestátními aktéry. ${ }^{2}$ I když transnacionální nevládní organizace existovaly a fungovaly $\mathrm{v}$ mezinárodní politice i v minulosti, jejich počet a množství oblastí, v nichž fungují, nikdy nedosahovaly současných měřítek: „,[O]d summitů OSN o sociálních otázkách nebo životním prostředí po konfliktní situace v Kosovu, od globálního odporu vůči Mnohostranné dohodě o investicích k lokálnímu lidskoprávnímu aktivismu v Mexiku, Barmě nebo Timoru a od mediálních korporací obepínajících zeměkouli ke kampaním domorodého obyvatelstva" (Anheimer et al. 2001: 4).

Systematický pokus o zmapování fenoménu globální občanské společnosti podávají od roku 2001 ročenky vydávané London School of Economics and Political Science (viz GCS 2004). V centru jejich zájmu stojí především transnacionální (respektive mezinárodní) nevládní organizace (INGOs), které významně spoluutvářejí organizační infrastrukturu globální občanské společnosti (následující shrnutí je parafrázováno z Kaldor et al. 2003: 14). V roce 1906 existovalo 169 INGOs a jen dvě z nich měly centrum mimo Evropu. Do roku 1938 mělo své centrum mimo Evropu 36 INGOs z celkového počtu 705 . V roce 1950 byla tato čísla 124 a 804. Za tímto nárůstem stály nové organizace založené po vzniku OSN v USA. V 50. a 60. letech se počet INGOs zvýšil na 1768, z čehož mělo 83 procent své centrum 
v Evropě, 10 procent v USA a mezi jedním a dvěma procenty v Asii, Jižní Americe, Střední Americe, na Středním Východě, v Africe a Austrálii. Do roku 2001 se tato struktura relativně decentralizovala, byla však stále organizována kolem dvou hlavních center, západní Evropy a Severní Ameriky. Mezi deseti zeměmi, na jejichž teritoriu se nachází nejvíce sekretariátů mezinárodních nevládních organizací tak figuruje osm evropských zemí (Velká Británie, Francie, Švýcarsko, Belgie, Nizozemí, Německo, Itálie a Rakousko) společně s USA a Kanadou. Paříž, Londýn, Brusel, Ženeva a New York si tak udržují své centrální postavení.

$\mathrm{V}$ posledních letech přitom nejvyšší nárůst členství zaznamenal region střední a východní Evropy, což zřetelně souvisí s pádem socialismu ve východoevropských zemích (tamtéž: 13). Obecně rostl v 90. letech 20. století počet jednotlivců účastnících se aktivit občanské společnosti nejvíce ve středně př́ijmových zemích spíše než v zemích nízko a vysoko př́ijmových (tamtéž: 14). Podle interpretace Kaldorové a jejích spolupracovníků díky tomu dochází k postupné dekoncentraci aktivit globální občanské společnosti: „V organizačním smyslu je dnes globální občanská společnost méně fenoménem Západu než byla v minulosti a její podstatný nárůst v posledních letech zvětšil její dosah mimo Severní Ameriku a Evropskou unii““ (tamtéž).

Infrastruktura globální občanské společnosti se však stala nejen robustnější, ale také více vzájemně provázanou a zároveň navázanou na mezinárodní (mezivládní) organizace, které nevládním aktérům poskytují př́iležitosti pro jejich činnost. Není tak náhodou, že nejvyšší počet transnacionálních nevládních organizací umíst’uje své sekretariáty do Ženevy, Paříže, Bruselu či New Yorku. Tato města jsou totiž sídly významných mezinárodních organizací, poskytují tak přirozená místa pro ovlivňování mezinárodní politiky. I když se mezinárodní organizace nesnaží transnacionální mobilizaci explicitně podporovat, přitahují jejich struktury aktivity nevládních organizací, zájmových skupin a sociálních hnutí a fungují tak jako jakési „magnety“ (Risse-Kappen 1995, O’Brien et al. 2000, Galtung 2000, Tarrow 2001, 2002, Keohane a Nye 2001). Podle S. Tarrowa jsou mezinárodní instituce nejpravděpodobnějšími arénami, v nichž se transnacionální aktivismus může profilovat vůči státům. Ačkoli jsou budovány za účelem vzájemné kooperace mezi státy, slouží také jako nezamýšlené př́ležitosti k mobilizaci proti nim (Tarrow 2001: 16). Proto i přes to, že Kaldorová se svými spolupracovníky zdůrazňují postupnou decentralizaci činnosti INGOs, tato decentralizace má zřetelná omezení. Pokud nedojde k většímu rozptylu center mezivládních organizací, nelze rozumně očekávat, že by INGOs radikálně decentralizovaly svou činnost a dobrovolně se tak zbavovaly př́stupu do politických procesů na mezinárodní úrovni.

Vedle INGOs se však v posledních letech rozvíjí také podstatně odlišná forma přímé politické mobilizace. Především v souvislosti s vystoupením alterglobalizačního hnutí (respektive hnutí za globální sociální spravedlnost, viz také Barša a Císař 2004) se začalo diskutovat o nových podobách globálního aktivismu, který není navázán na formální infrastrukturu INGOs. Naopak - podle některých analýz umožnila současná expanze prostředků elektronické komunikace rozvoj nového typu individualizované občanské participace, která se od „tradičního“ aktivismu nevládních organizací výrazně liší (Bennett 2005, pro shrnutí a diskusi viz Tilly 2004: 106-108).

Podle Bennetta otevřelo využití informačních technologií prostor pro politický aktivismus, který: (1) není založen na organizační práci INGOs, ale na existenci volně strukturovaných sociálních sítí prostředkovaných elektronickými médii; (2) umožňuje permanentní kampaně, 
které nejsou kontrolovány INGOs, ale málo koordinovaným způsobem probíhají v globálním komunikačním prostoru a rychle stř́́dají své bezprostřední cíle; (3) vyrůstá z individualizované (neexkluzivní) participace, která není založena na formálním členství nebo ideologické orientaci a (4) otevírá možnosti pro rozvoj organizací pracujících na více tématech. Proto se odlišuje od aktivismu INGOs, který: (1) se koncentruje na konkrétní problémy (single-issue networks), (2) je založen na centrálně koordinovaných (a dočasných) kampaních koalic organizací a (3) je zaměřen na politickou (institucionální) změnu (Bennett 2005: 213-25). Základní rozdíly shrnuje následující tabulka.

Tabulka 2: Aktivismus INGOs versus „nový“ aktivismus

\begin{tabular}{|c|c|c|}
\hline kritéria & aktivismus INGOs & „nový“ aktivismus \\
\hline agenda & $\begin{array}{r}\text { prosazování zájmů a obhajoba zásadových } \\
\text { myšlenek }\end{array}$ & $\begin{array}{r}\text { rozmanitá agenda týkající se sociální } \\
\text { spravedlnosti }\end{array}$ \\
\hline organizace & $\begin{array}{r}\text { sítě NGOs koncentrované kolem konkrétních } \\
\text { problémü }\end{array}$ & $\begin{array}{r}\text { masový a zároveň individualizovaný } \\
\text { aktivismus nenapojený na konkrétní problém }\end{array}$ \\
\hline cíle & vlády a korporace & $\begin{array}{r}\text { korporace, průmyslové sektory, mezinárodní } \\
\text { finanční organizace }\end{array}$ \\
\hline taktika & $\begin{array}{r}\begin{array}{r}\text { strategické kampaně s omezenými politickými } \\
\text { cíli a kontrolované NGOs }\end{array} \\
\end{array}$ & $\begin{array}{r}\text { permanentní kampaně s rozmanitými cíli bez } \\
\text { schopnosti NGOs kontrolovat je }\end{array}$ \\
\hline dopad & $\begin{array}{r}\text { proměna legislativy, ustavení informačních } \\
\text { režimů, udržení organizační identity }\end{array}$ & $\begin{array}{l}\text { osobní zapojení do prímé akce, ustavení } \\
\text { komunikačních sítí, uschopnění jednotlivců }\end{array}$ \\
\hline kapacita & reformy a intervence v krizových situacích & masové protesty, proměna hodnot \\
\hline
\end{tabular}

Zdroj: Bennet† 2005: 214 (upraveno).

\section{Zaměření aktivit globální občanské společnosti}

Zaměření globální občanské společnosti tvoří poslední sledovanou dimenzi jejího výzkumu. V roce 2001 činnostem INGOs dominovaly dvě oblasti - ekonomický rozvoj (26,1 procent) a výzkum a vývoj (20,5 procent). Tyto sféry činnosti představovaly primární oblasti zájmu mezinárodních nevládních organizací i v minulosti, nebot’ jsou to právě tyto oblasti, které vyžadují vysokou míru mezinárodní koordinace a spolupráce (Kaldor et al. 2003). V 90. letech 20. století však zaznamenaly dramatický nárůst organizace zaměřující se na humanitární, politické a morální cíle. Tomuto typu aktérů se dostalo pozornosti jako ,transnacionálním advokačním sítím“ (TAS), jejichž důležitou část tvoří právě různé nevládní organizace a sociální hnutí (Keck a Sikkink 1998). Jejich činnost tvořila páteř výše definovaného „tradičního“ aktivismu INGOs. Nejprve se proto zaměříme na jeho expozici, následovat bude stručné srovnání s „novým“ aktivismem.

Koncept TAS popisuje sítě politických aktivistů a jejich organizací, které se formují transnacionálně kolem určitého politického problému. Tito aktéři se vyznačují především tím, že se formují v takových politických oblastech, které charakterizuje vysoký normativní obsah - obhajoba lidských práv, práv žen či ochrany životního prostředí. Identita takto tvořené sítě je stmelena na základě určité zásadové myšlenky, kterou komponenty sítě sdílejí. Jednání TAS se proto vymyká úzce racionalisticky chápané koncepci zájmových skupin (viz Olson 1970), které prosazují materiální zájem určité konkrétní sociální skupiny, jejíž členové se na aktivitách dané organizace přímo účastní (např́iklad odborové organizace). 
TAS naopak prosazují zájmy, které nevycházejí z konkrétního postavení určité skupiny v sociální struktuře, ale odrážejí univerzalisticky chápané principy, které by měly potenciálně platit pro každého jednotlivce (např́klad lidská práva). Jejich činnost je tak často navázána na existenci mezinárodních norem. TAS jednak pomáhají při prrijímání a prosazování těchto norem, jednak je uvádějí do praxe tím, že zaměřují svou aktivitu na ty aktéry, kteří je porušují. Jejich funkce je proto nejvýznamnější ve fázi nastolování problému na mezinárodní úrovni (tzv. agenda setting) a poté, kdy byla norma státy přijata, tj. Ve fázi její implementace (Risse 2003: 265). Ve fázi implementace pak možnost odkázat se k mezinárodně uznané normě vybavuje TAS dodatečnou legitimitou, která jim za určitých podmínek umožňuje uspět i proti relativně silnějším protihráčům - nejčastěji státům, ale také velkým korporacím (srov. Evans 2000).

TAS jsou tvořeny mezinárodními a domácími nevládními organizacemi, domácími sociálními hnutími, nadacemi, zástupci médií, církví, odborů a intelektuálů, částmi regionálních a mezivládních organizací a vládních agentur (Keck a Sikkink 1998: 9). Formují se především v těch př́padech, kdy jsou uzavřeny komunikační kanály mezi domácími politickými aktéry a státem a kdy političtí aktivisté věří, že mohou svůj politický vliv zvýšit mobilizací aktérů operujících vně státních hranic. Transnacionální vazby jim totiž umožňují zmobilizovat zahraniční skupiny aktivistů, které se pokoušejí přesvědčit jiné státy a mezivládní organizace, aby na uzavřený nebo represivní režim uvalily sankce, podmínily spolupráci s tímto režimem uvolněním domácí represe atd. Represe či přehlížení, které režim adresuje domácím kritikům, se mu takto zprostředkovaně vracejí jako bumerang. Odtud Kecková a Sikkinková odvozují název tohoto modelu - mechanismus bumerangu (tamtéž: 13).

Řekli jsme, že TAS se formují především v oblastech s vysokým normativním obsahem. Když pak sečteme mezinárodní nevládní organizace působící ve všech těchto sektorech advokační, politické a náboženské INGOs -, dostaneme skupinu organizací, která je dokonce rozsáhlejší než organizace působící v oblasti výzkumu a vývoje (obsahuje 23 procent všech INGOs) (Kaldor et al. 2003: 15-16). Př́kladů působení advokačních INGOs je bezpočet. Bez sítí těchto organizací by nebyl (s takovou rychlostí) přijat statut Mezinárodního trestního soudu (Glasius 2002), nebyla by věnována taková pozornost problematice porušování lidských práv (Clark 2001), ani by nebyla přijata mezinárodní konvence proti používání nášlapných min (Scott 2001).

Tato (sít’ová) charakteristika současné globální politiky pak v sobě podle některých interpretací skýtá naději na flexibilní řešení aktuálních globálních problémů. Např́íklad David Held (2004) navazuje na J. F. Rischarda a hlásí se k jeho návrhu „globálních sítí zaměřených na problémy“ (global issues networks, GINs), které by měly být formovány ze zástupců všech společenských sfér kolem konkrétních globálních otázek. Jejich úkolem by byla detailní analýza problémů, formulace řešení a implementace těchto řešení. Globální občanská společnost by tak převzala politickou iniciativu a pomohla by při řešení těch problémů, které současný svět trápí nejvíce - chudoby, pandemie AIDS či mezinárodního terorismu.

Jak jsme viděli v předchozí sekci, vedle těchto instrumentálně orientovaných organizačních útvarů se v globálním prostoru propojují také decentralizované sítě ,nových“ aktivistů, jimž primárně nejde o formální organizaci, ale o př́mou akci a individuální uschopnění (Bennett 2005). V protikladu k sítím NGOs mají tyto elektronickou komunikací prostředko- 
vané sítě interpersonální charakter a jsou polycentrické. Chybí jim jednotné koordinační centrum i formalizovaná organizační struktura. Namísto konstrukce kolektivní identity jim jde o zahrnutí různosti - vytvářejí sítě „slabých vazeb“, které sice jednotlivce efektivně propojují s druhými, ale na druhé straně je neintegrují pod jednotnou organizační nálepkou ani nevyžadují silnou vnitřní identifikaci s takto vytvořenou strukturou (pro koncept „slabých vazeb“ viz Granowetter 1973). S tím souvisí také nečlenský charakter takto utvořených sítí - účastníci se nestávají jejich členy, ale vstupují do nich a vystupují z nich. Strategický repertoár takových sítí není založen na kampaních, ale na celoročním „protestním kalendáři“, který je sítí sdílen (Bennett 2005: 215). Díky jejich charakteru je pro takové sítě jednodušší propojovat rozdílné sociální segmenty a překonávat sociální vzdálenost mezi potenciálními účastníky. To je jen podtrženo absencí jasné ideologické náplně sítě, která proto na ulicích dokáže mobilizovat jak vysokoškolské studenty a pedagogy, tak nekvalifikované dělníky a zemědělce.

\section{Občanská společnost a demokracie: kontrola globalizace}

Politická organizovanost ,vně státních hranic“ je v některých interpretacích viděna jako odpověd' na postupující ekonomickou a kulturní globalizaci. V Habermasově perspektivě se dnes opakuje střet systémové a sociální integrace, který charakterizoval západní modernitu, na globální úrovni. Habermas popisuje př́íchod moderní společnosti jako proces, který otevřel předmoderní horizonty sdíleného životního světa. Modernita tak vystavila jednotlivce ambivalentnímu zážitku: osvobození od tradičních (místně vázaných) forem kolektivní existence s sebou zároveň přineslo vystavení nejistotě života bez ,„prrirozených“ záchytných bodů. Aby toto vyvázání nemělo patologické důsledky (anomie a rozpad společnosti), otevřený svět života musel být znovunavázán na vyšší úrovni - v rámci národního demokratického státu (Habermas 1998a).

Podobně jako v době (první) modernity dnes globalizace otevřela „přirozený“ horizont moderního člověka poskytovaný národním státem. A stejně jako tehdy je dnes podle Habermase nutné, aby politika dohnala ekonomiku, tj. aby došlo k uzavření (sociální integraci) opět na vyšší úrovni tak, aby byly zachovány nejméně ty podmínky demokratického sebeurčení, které byly rozvinuty na úrovni národního státu. Habermas odkazuje k Polanyiho Velké transformaci (Polanyi 1957), který zde popsal destruktivní sociální a lidské konsekvence budování volného trhu v 19. století. Polanyi tak zdůraznil potřebu politického řádu, který by dokázal moderní ekonomický systém znovu zapustit do substrátu politických a sociálních institucí. Podle Habermase byl tento systém po 2. Světové válce ztělesněn Brettonwoodským systémem, který však díky nástupu finančních trhů a kapitálové mobility vzal již před třiceti lety za své (srov. také Ruggie 1994). Národní horizont byl otevřen a my dnes opět stojíme na prahu ,velké transformace“, na niž nelze reagovat jinak než obnovením demokratické sebekontroly společnosti na vyšší - nadnárodní - úrovni (Habermas 1998a).

Habermas má konkrétně na mysli Evropskou unii, jejíž politická infrastruktura by měla vyvázané tržní síly ,uzavř́ít“ v rámci evropského demokratického procesu. Habermas v neofunkcionalistickém duchu věří, že by posun politických kompetencí na evropskou úroveň motivoval rozvoj plnokrevné evropské občanské společnosti, která by zajišt'ovala nejen komunikaci mezi dnes národně segmentovanými politickými veřejnostmi, ale také nezprostředkovanou politickou participaci: „Ohnisko politiky by se do určité míry posunulo z ná- 
rodních hlavních měst do evropských center - nejen skrze aktivity lobbistů a komerčních zájmů, které jsou v Bruselu již nyní docela silně zastoupeny, ale skrze aktivity politických stran, odborů, občanských a kulturních sdružení, skupin sledujících veřejný zájem, sociálních hnutí a ,nátlak z ulice““ (Habermas 2001: 17). Evropské občanství by tak získalo své aktivní (demokratické) vyjádření - zformovala by se evropská občanská společnost, která by podle Habermase dokázala dát impuls procesu konstituce společného evropského vědomí (evropské identity). Politická participace prostředkovaná institucemi evropské občanské společnosti by tak přispěla $\mathrm{k}$ demokratické reformě evropského vládnutí.

Zatímco na evropské úrovni by tak podle Habermase mohla být replikována zkušenost moderních demokratických států vyrůstající z realizace práv politické participace v institucích občanské společnosti, na globální úrovni pro takový projekt chybí nutné sociální zdroje a sdílená historie. Jak jsme však již řekli, neznamená to, že by Habermas viděl globální politiku očima realistického paradigmatu. I když neexistuje globální veřejná sféra, která by poskytovala platformu globální politické participaci (viz tabulka 1: radikálně-demokratická tradice), „ústřední role, kterou hraje nový typ organizací - totiž nevládních organizací jako Greenpeace nebo Amnesty International - [...] v tvorbě a mobilizaci transnacionálních veřejných sfér je přinejmenším indikací rostoucího dopadu, který mají na tisk a média aktéři, kteří konfrontují státy zevnitř sítě mezinárodní občanské společnosti“ (Habermas 1998d: 177). V Habermasově modelu deliberativní demokracie aplikovaném na globální úrovni (viz tabulka 1) mohou organizace občanské společnosti jen stě̌̌i poskytovat infrastrukturu demokratické participaci, mohou však ovlivňovat globální veřejné mínění a přispívat $\mathrm{k}$ transparentnosti politického rozhodování v doposud uzavřených mezinárodních organizacích. Jejich nejdůležitější funkcí je pak propojování globální politické arény s jednotlivými národními politickými veřejnostmi.

Habermas se omezuje na analýzu podmínek konstrukce evropského demokratického občanství a nevěří v možnost jeho globální extenze. ${ }^{3}$ Podle jiných názorů je však rozvinutí globálního občanství jediným receptem na řešení současných problémů. Tito autoři (nejvýrazněji reprezentovaní britským teoretikem $D$. Heldem) věrí v prospěšnost a možnost demokratizace globálních politických institucí a rozvoje globálního politického občanství, které by mělo být základem skutečně spravedlivé „globální společnosti“ schopné čelit rostoucím globálním nerovnostem, bídě, degradaci životního prostředí i neoimperiálním ambicím v současnosti dominantních globálních hráčů. I ti by totiž měli být podřízeni všeobecně platným pravidlům, která by všem jednotlivcům poskytovala rovný ohled a představovala by tak základ globální republiky rovných světoobčanů. Ta by nejen nastolila Kantem ohlášený světový mír, ale ve svých ambicích by se přibližila požadavkům skutečně globální spravedlnosti.

V krátkodobém výhledu jde Heldovi o reformu hlavních institucí fungujících pod hlavičkou OSN (např́klad Rady bezpečnosti) tak, aby i bývalé rozvojové země mohly získat podstatný vliv na rozhodování, o rozšiřrení institucionální struktury OSN, zajišsění efektivního fungování Mezinárodního trestního soudu a ustavení použitelné mezinárodní vojenské síly. To vše by mělo být doplněno podporou participace občanských organizací a sociálně slabých skupin při rozhodování na globální úrovni (Held 1997, 2004). V dlouhodobém výhledu jde o nastolení globálního kosmopolitního práva, ustavení globálního parlamentu a separaci politické a ekonomické moci veřejnou podporou občanské participace a přesunem donucovacích kapacit z národní na globální a regionální úrovně (Held 1997, 1999, 2000, 2004). Podle Helda 
by kosmopolitní právo „vyžadovalo podřizení regionálních, národních a lokálních suverenit všezahrnujícímu právnímu systému, $\mathrm{v}$ jehož rámci by však společenství na různých úrovních byla samosprávná“ (Held 1999: 107). V rámci tohoto systému by jedinci měli vícenásobné občanství - byli by občany svých bezprostředních politických jednotek a k tomu by participovali $\mathrm{v}$ širších, regionálních a globálních společenstvích. Tímto způsobem by došlo podle Helda k nastolení demokratické kontroly nad v současnosti v globální aréně rozptýlenými mocenskými centry, která - pokud by byla ponechána vlastnímu osudu - hrozí vytvořením nepřehledného a chaotického světového rádu, který bude připomínat předmoderní formy rozptýlené politické autority bez demokratické kontroly.

Jak jsme řekli již v úvodu, podle této perspektivy má být rozvoj globální občanské společnosti předstupněm veřejné kontroly globální ekonomiky i používání vojenské síly. Jinými slovy řečeno, má být předstupněm realizace participativní demokracie na globální úrovni. Vedle Habermase, který upozornil na překážky tohoto globálního projektu, existují i prŕstupy, které svůj skepticismus rozšiřují i na možnost rozvinutí evropského občanství.

\section{Politický aktivismus versus občanství}

Moderní koncepce občanství se historicky rozvinula ruku v ruce $\mathrm{s}$ institucí národního státu. Lid, který se stal zdrojem legitimity politické autority po zpochybnění jejího mimosvětského ukotvení v boží vůli, se tak překryl s moderním národem. Podle Habermase však vnitřní souvislost mezi „lidem“ (jako zdrojem suverenity moderního státu) a „národem“ (jako zdrojem kolektivní identity obyvatel tohoto státu) neměla konceptuální, ale jen historický charakter: „Národní stát podněcoval úzký vztah mezi ethnos a demos pouze dočasně. Svým pojmem bylo státní občanství vždy nezávislé na národní identitě“ (Habermas 1996: 495, 2004 : 189). Právě to Habermasovi umožnilo, aby si byl schopen představit realizaci politických práv (demokratického občanství) také na evropské úrovni.

Habermas neváže možnost evropské demokracie na existenci předpoliticky definovaného národa jak to činí euroskeptici (viz níže Kymlicka), ale obrací směr jejich argumentu: namísto toho, aby čekal, až dojde ke konstituci evropského národa tvořícího potřebný substrát nadnárodní demokratizace, hovoří o nutnosti zavedení určitých politických mechanismů, které ke konstituci evropského národa mohou nakonec přispět. K tomu došlo již jednou - na národní úrovni - a není důvodu se domnívat, že by nemohlo podobným způsobem dojít ke konstituci nového kolektivu se sdílenou - $\mathrm{v}$ tomto př́padě evropskou - identitou. Moderní národ není přirozeným útvarem, ale politicky konstruovanou entitou, která vykrystalizovala jako výsledek politické mobilizace občanů s volebním právem v rámci moderní veřejné sféry (Habermas 1998a, 2001). Národní vědomí vyrostlo z demokratické mobilizace prostřednictvím masových médií (tisku) a stranické politiky. Národní vědomí (společná identita) tak nebylo předpolitickým předpokladem demokratického procesu, ale produktem tohoto procesu.

S tím nesouhlasí ti teoretici, kteř́ naopak vztah „lidu“ a „národa“ vidí jako konceptuálně nutný. Will Kymlicka zdůrazñuje význam politické komunikace v místním jazyce jako páteře moderní demokratické politiky (Kymlicka 1999, 2002). Proto podle něj nelze očekávat, že by občané různých zemí hovořící různými jazyky preferovali změnu ohniska politické činnosti na jim neznámou - nadnárodní - úroveň, která by je zbavila možnosti jejich rodný jazyk 
používat. Nejenže nelze nic takového očekávat na globální úrovni, ale ani v rámci sjednocené Evropy se nezdá, že by Dánové chtěli začít př́mo komunikovat např́ílad s Italy. V jakém jazyce, ptá se Kymlicka a staví se tak kriticky k návrhům demokratizovat EU cestou zvyšování pravomocí Evropského parlamentu (EP). Posílení EP by automaticky znamenalo snížení odpovědnosti EU, která se realizuje skrze národní reprezentace, a znemožnilo by sledování zájmů občanů pomocí mobilizace jejich národních spoluobčanů. Aby mohla skupina občanů něčeho dosáhnout, musela by vstoupit do přímé interakce s občany v jiných zemích. Pro to však neexistují ani podmínky (nadnárodní veřejná sféra tvořená společnými médii a sdíleným jazykem), ani ochota na straně občanů evropských zemí. Snaha o demokratizaci EU tak může paradoxně vyústit ne ve snížení, ale ve zvýšení tolik diskutovaného demokratického deficitu EU: „Posunulo by to moc z národní úrovně, kde je možná masová participace a činorodá demokratická debata ve společném jazyce, $\mathrm{k}$ nadnárodní úrovni, kde je demokratická participace a deliberace velmi obtížná“ (Kymlicka 2002: 315).

To však neznamená, že by se Kymlicka stavěl proti participaci nevládních organizací a sociálních hnutí v mezinárodní politice. Naopak - podporuje globální rozšiřování lidských práv a občanského aktivismu, nevěři však, že by touto cestou mohlo dojít $\mathrm{k}$ demokratizaci nadnárodních organizací (včetně EU). Politický aktivismus na nadnárodní úrovni a globální demokratické občanstvi jsou dvě odlišné věci (Kymlicka 1999: 124). Zatímco první z nich se může za současných podmínek rozvíjet, druhého nemůže být dosaženo prostě proto, že na nadnárodní úrovni neexistuje žádný „lid“ (demos), který by mohl být nositelem občanství a mohl tvořit smysluplný základ politické deliberace a demokratického politického procesu.

Zatímco na národní rovině je lid definován ve smyslu národa, na nadnárodní úrovni žádná fungující koncepce světonároda neexistuje. Občanství bylo naroubováno na kulturně definovaný kolektiv moderního národa a podle skeptiků je při neexistenci „nadnárodního lidu“ nepřenositelné na úroveň vyšší. Kymlicka tak univerzalizuje Habermasovu nedůvěru, kterou vyjádřil ve vztahu k plánům globální demokratizace. Podle Kymlicky se netýká jen globální, ale také evropské demokracie. Nevládní organizace, sociální hnutí („tradiční“ aktivismus) i elektronicky koordinovaní jednotlivci (,nový“ aktivismus) tak mohou propojovat různé politické arény a ovlivňovat globální (respektive evropskou) výměnu informací (zajištovat komunikaci a zvyšovat transparentnost, viz tabulka 1), nemohou však zajistit výkon politických práv (tj. demokratickou participaci).

\section{Kritika globální občanské společnosti: patologie aktivistických elit}

Na omezenou schopnost nevládních organizací a jejich sítí poskytovat na nadnárodní úrovni infrastrukturu politické participaci vedle politických filosofủ upozorňují také teoretici kolektivního jednání. Podle jednoho z nich - S. Tarrowa - totiž na nadnárodní úrovni chybí rozvinuté sociální sítě a kulturní zdroje, které by umožňovaly konstrukci transnacionálních identit sociálních hnutí. Proto lze o mobilizaci sociálních hnutí uvažovat na úrovni města, regionu či národního státu, na úrovni nadnárodní je to naopak daleko těžší (Tarrow 2000: 20). Tarrow si nevšímá potenciálu „nového“ aktivismu (s jeho důrazem na individualizovanou formu politické participace), a proto je přesvědčen, že na nadnárodní úrovni se dnes občanská společnost organizovat nemůže. Tato sféra spadá do oblasti zájmu elitních aktivistů jednotlivých INGOs. 
Zatímco Kaldorová a její spolupracovníci (viz výše) rostoucí počet INGOs chápou jako důkaz občanské samoorganizace na globální úrovni, Tarrow vidí INGOs jako samotný projev nemožnosti této samoorganizace. To, co je dnes označováno jako globální občanská společnost, není ničím jiným než skupinou elitních a vzdělaných profesionálů, kteří sledují své zájmy bez ohledu na konkrétní lokální potřeby a nezřídka spíše v protikladu k nim. Zatímco národní občanské společnosti tvoří relativně široká sociální hnutí, globální občanská společnost je ideologickým konstruktem globálních aktivistů, kterým chybí napojení na domácí sociální ,základny“ (constituencies). Na rozdíl od transnacionálního sociálního hnutí, které by muselo být „,integrováno v několika společnostech, sjednoceno ve svých cílech a organizaci a schopno organizovat protest proti různým typům cílů“ (Tarrow 1998: 185), transnacionální advokační sítě (viz výše, též Keck a Sikkink 1998), které vyplňují prostor mezinárodního aktivismu, nejsou v domácích sociálních sítích nijak ukotveny. Proto nejsou autentickými hnutími: chybí jim permanentní sociální vazby a zakotvení v určité politické kultuře.

To může v některých případech vést až k tomu, že mocné a byrokratizované mezinárodní nevládní organizace umlčují lokálně artikulované zájmy a v horším prrípadě si je samy konstruují. Globální kampaně za prosazování „lokálních“ zájmů jsou tak připravovány bez konzultace oněch zájmů, jež mají reprezentovat. Podle N. Chandhokeové se proto musíme u každé kampaně globální občanské společnosti ptát, do jaké míry byli lokální aktéři konzultováni před př́pravou konkrétní akce, a byli-li vůbec konzultováni. Musíme se ptát, zdali aktéři globální občanské společnosti vưbec někoho reprezentují a zvláště reprezentují-li někoho ve třetím světě, který tvoři jádro aktivit INGOs. Nejsou tyto organizace jen „samozvanými mluvčími lidí, kteří nemají ani tu nejmenší možnost ovlivnit jejich agendu?“" ptá se Chandhokeová (2002: 47).

Tyto problémy se přitom netýkají „pouze“ zemí třetího světa. Budování občanské společnosti v zemích bývalého východního bloku po pádu železné opony prošlo podobnými peripetiemi. Mezinárodní programy zaměřené na podporu občanského sektoru a nevládních organizací trpěly od svého počátku malou senzitivitou ke specifikům lokálních podmínek, v nichž byly tyto programy implementovány. Lokální zájmy nebyly na počátku brány v úvahu a podporu mohly obdržet pouze ty organizace, které dokázaly odpovědět na požadavky mezinárodních agentur a jimi financovaných transnacionálních nevládních organizací. Podle některých kritických komentářů takové programy nevedly k vybudování fungující struktury občanské společnosti, ale izolovaných enkláv ,aktivistů“, které si díky svému privilegovanému prŕístupu do „globální občanské společnosti“ dokázaly zajistit stabilní př́sun štědrých grantů, nedokázaly však navázat vztahy s lidmi, které údajně reprezentovaly a jejichž zájmy měly prosazovat (Carothers 1999).

Dopad transnacionálních sítí měl v tomto případě velmi ambivalentní výsledky. Namísto uschopnění lokálních politických aktérů došlo k jejich depolitizaci - místo toho, aby programy motivovaly občanské aktivisty k př́mému zapojení se do politiky, kultivovaly mezi nimi kulturu závislosti. Aktivisté se tak místo př́imé politické činnosti věnovali především psaní žádostí o granty. Důsledkem těchto programů pak nebylo budování občanské společnosti, ale její zneschopňování. Patrice McMahonová, která provedla rozsáhlý výzkum mezi ženskými skupinami v Polsku a Mad'arsku, dokonce tvrdí, že mezinárodní pomoc vlastně zabraňovala 
konstituci lokálních sociálních hnutí, protože orientací lokálních skupin na transnacionální zdroje zbavovala mezinárodní pomoc tyto skupiny motivace ke spolupráci na lokální úrovni (McMahon 2001, srov. také Mendelson a Glenn 2002).

Stejně tak tyto programy bránily lokálním aktivistům, aby definovali své vlastní priority, pro něž by mohli získat finanční podporu. Naopak - byli to transnacionální aktéŕi, kteří rozhodovali o lokálních prioritách. Podle McMahonové (a dalších kritiků, viz např́klad Wedel 1998) tak tyto transnacionálně koordinované programy nepřispěly ke konstituci občanského sektoru, ale k mocenské manipulaci s místními podmínkami občanského aktivismu: „Tím, že identifikují ,oblasti zájmu“ nebo regionální priority, jsou americké nevládní organizace schopny ,definovat agendu“ pro ženské skupiny $\mathrm{v}$ regionu. Tato druhá tvář moci je pravděpodobně stejně rafinovaná jako moc komunistické strany, protože také omezuje volby a formuje způsob, jakým jednotlivci vnímají a reagují na své prostředí“ (McMahon 2001: 59).

\section{Namísto závěru: globální občanská společnost a demokracie}

Vystoupení transnacionálních nevládních organizací, sociálních hnutí i elektronickými komunikačními prostředky podporovaná mobilizace hnutí za globální sociální spravedlnost spadá časově vjedno s politickou a technologickou globalizací (viz také Josselin a Wallace 2001). Př́ležitosti pro transnacionální občanský aktivismus byly vytvořeny díky konci studené války, pádu sovětského impéria a boomu elektronických komunikačních médií. Konec studené války vytvořil př́znivé podmínky pro mezinárodní politickou kooperaci, která zase poskytla vhodné prostředí pro transnacionální politický aktivismus. Mezinárodní organizace, jejich summity a mezinárodní režimy a normy vytvářejí pro transnacionální aktéry př́ležitosti pro politické jednání. Rozpad Sovětského svazu navíc na počátku 90. let uvolnil překážky interní demokratizace v mnoha zemích světa - zvláště pak ve východní a střední Evropě. Právě proto v 90. letech 20. století v tomto regionu vzrostl počet členů INGOs nejvíce. Liberalizace a demokratizace států tak vytváŕí nutnou politickou podmínku existence globální občanské společnosti. Jen občané těch zemí, které jim zajištují základní politická a občanská práva, budou moci aktivně vstoupit do politické interakce $\mathrm{v}$ rámci globální občanské společnosti.

Druhou (sociálně-ekonomickou) podmínkou fungování a existence globální občanské společnosti je príistup k prostředkům elektronické komunikace. Právě rozvoj internetu byl jednou z prŕíčin robustnějící transnacionální informační a politické výměny (Castells 1996, Keck a Sikkink 1998). Internet poskytl prostředek levné a neomezené komunikace, která tvoří nutnou podmínku jakékoli politické činnosti. Díky internetu se staly hranice prostupnějšími a vzdálenosti podstatně kratšími. Dnes se součástí globální občanské společnosti může stát kdokoli, kdo má př́stup k internetu. Vedle toho, že se zde může zapojit do př́mé organizační činnosti v rámci nějaké INGO, může se realizovat skrze „nový“ aktivismus, pro který jsou, jak jsme viděli, elektronické vazby nutným komplementem těch interpersonálních.

Třetí (kulturni) podmínkou, jak upozorňují Habermas i Kymlicka, je společný jazyk. Dnešní lingua franca (ne toliko globálního aktivismu) je angličtina. Podle Kymlicky tento fakt vytváří nepřekonatelnou překážku pro to, aby se mohlo rozvinout globální demokratické občanství. Ani na evropské úrovni nelze očekávat univerzální akceptaci jednotného komunikačního média. Habermas toto uznává na úrovni globální, na úrovni evropské naopak považu- 
je rozšíření angličtiny za nutnou podmínku politické a sociální integrace kontinentu. Evropská veřejná sféra se má rozvinout tehdy, když se sobě navzájem otevřou národní veřejnosti. $\mathrm{K}$ tomu je třeba, aby vzdělávací systémy evropských zemí poskytly každému evropskému občanovi dostatečné jazykové předpoklady pro jeho participaci v evropské politice - evropští občané potřebují společný jazyk, i když to (ve většině prrípadů) nebude jejich mateřský jazyk, ale právě angličtina (Habermas 1998c, 2001).

Politická a občanská práva, přístup k internetu (a schopnost jej využívat) a znalost angličtiny tak tvoří nutné podmínky „tradičního“ i „nového“ aktivismu (viz tabulka 2). Ani jednu z těchto podmínek struktury globální občanské společnosti zajistit nemohou. První je zajišt’ována jednotlivými státy, druhou a třetí determinuje úroveň ekonomického rozvoje (srov. Wade 2002). Jinými slovy řečeno, globální občanská společnost (respektive globální politický aktivismus) je strukturována „domácími“ politickými a ekonomickými podmínkami.

Ty jsou natolik heterogenní, že nelze očekávat vytvoření globálního prostoru politické participace (občanské společnosti) v silném slova smyslu. Jeho institucionalizace by totiž vyžadovala nejen zajištění rovných občanských a politických práv na globální úrovni, ale také redistributivní politiky tamtéž. Šlo by ve skutečnosti o realizaci některé z vizí globální sociální spravedlnosti (srov. např́íklad Barry 1999, Pogge 2002, Held 2004). Globální politický prostor však zůstává fragmentovaný a závislý na národnich zdrojich politické participace (politických právech, ekonomických zdrojích a vzdělání). Neznamená to sice, že by proto neexistoval potenciál pro zapojení transnacionálních nevládních organizací, sociálních hnutí a jednotlivců do politických aktivit na této úrovni; a existuje celá řada př́kladů, které to dokládají. Znamená to však, že nelze v dohledné době očekávat rozvoj globálního demokratického (aktivního) občanství. Otázkou dokonce zůstává, zdali lze rozumně očekávat rozvoj demokratického evropského občanství, když střízlivé analýzy ukazují, že i přes velmi silné zapojení nejrůznějších politických organizací v evropské politice těmto aktérům zcela chybí schopnost poskytovat vertikální kanály participace občanům členských států EU (Greenwood 2003: 269, Magnette 2003).

V mnohoúrovňové struktuře dnešní globální politiky proto nelze od politického aktivismu očekávat uskutečnění radikálně-demokratických vizí př́mé participace (viz tabulka 1). Dokonce ani v (habermasovské) proceduralistické verzi. Vně hranic demokratického státu neexistují žádné institucionální mechanismy, které by zajištovaly, řečeno s Rousseauem, Kantem a Habermasem, veřejnou autonomii občanů. Na nadnárodní úrovni občané neexistuji, namisto nich se zde pohybuji aktivisté. Nebo přesněji: na této úrovni se pohybují občané (některých) států jako globální aktivisté. Ti mohou čas od času pomoci prosadit důležitou konvenci, vznést na mezinárodní agendu přehlížený problém (ovlivnit politickou komunikaci) a konstantně nutit mezivládní organizace $\mathrm{k}$ větší transparentnosti (viz tabulka 1 ). $\mathrm{V}$ tomto smyslu mohou vynášet prvky liberální politické kultury a občanského étosu vně státních hranic (pokud jsou sami schopni dostát požadavkům transparentnosti), nemohou však předstírat, že jsou nositeli (globální) lidové suverenity.

S tím souvisí také agenda, kterou by měla mít „globální občanská společnost“ aspiraci řešit. Nejde totiž primárně, jak si myslí D. Held a jiní globální optimisté, o reformu globálního politického pořádku. Cíle globální občanské společnosti nejsou nutně cíle globální. Jak dokazuje současná kampaň za uskutečnění rozvojových cílů tisíciletí, prostorem politického 
boje zůstávají jednotlivé státy. V tomto případě rozvinuté. Konečným cílem této i jiných kampaní pak je, aby byly podmínky občanské participace (tj. Veřejná autonomie) zajištěny i v těch zemich (tj. Opět: na úrovni států), které je dnes neposkytují. Jen tak bude možné, aby o řešení nejpalčivějších problémů dneška nerozhodovali jen politici a elitní aktivisté ze Severu, ale také ti, kterých se především týkají. Reforma globálního uspořádání by pak měla být jen prostředkem $\mathrm{k}$ dosažení tohoto základního cíle.

\section{Poznámky}

1 Stat' částečně využívá a dále rozpracovává autorem již dříve publikované výstupy, viz seznam literatury.

2 Data pro studie rostoucího počtu INGOs vycházejí zpravidla z Yearbook of International Organizations, kterou publikuje bruselská Union of International Associations od roku 1950. Např́klad Kathryn Sikkinková a Jackie Smithová se z tohoto zdroje snaží vytěžit data o těch organizacích, které se orientují na ,politickou či sociální změnu“. Srov. Sikkink a Smith 2002.

3 Zatímco některé texty (viz například Habermas 1998d, původní vydání 1996) umožňují Habermase interpretovat jako reprezentanta právního kosmopolitismu - zastánce kosmopolitní demokracie (pro takovou interpretaci viz Velek 2004: 246-47), jiné (viz Habermas 1998a) naopak zřetelně ukazují, že jeho morální kosmopolitismus se (v protikladu k teoriím kosmopolitní demokracie) nekryje s projektem globální demokratizace spojené s institucionalizací globální politické autority plnící funkce světového demokratického státu. Habermas zde upozorňuje na rozdíl, který panuje mezi možností politické (občanské) a sociální integrace evropského kontinentu a nemožností takové integrace na globální úrovni. Zatímco Evropané jsou podle Habermase schopni dát své kolektivní identitě společný eticko-politický obsah, globální společenství občanskou solidaritu generovat nedokáže. Ta je vždy založena na konkrétní kolektivní identitě, kterou diskurz lidských práv (na globální úrovni) není schopen podepř́t (tamtéž: sekce V). Vedle toho Habermas v konzervativním duchu naznačuje, že žádné kolektivní „my“ nemůže existovat bez konstitutivního „oni“. Všeinkluzivní globální pospolitost je neuskutečnitelná, nebot’ by zrušila možnost existence „konstitutivního vnějšku“. Toto Habermasovo nasazení vyplynulo čitelně na povrch v diskusi okolo transatlantické roztržky (2002-2003). Transatlantický rozštěp totiž pro Habermase představoval prŕislib evropské politické emancipace tváří v tváŕ jejímu konstitutivnímu druhému - USA (Habermas a Derrida 2003). Za tento vhled vděčím diskusi s Pavlem Baršou.

\section{Literatura}

Ancelovici, M. 2002. „Organizing against Globalization: The Case of ATTAC in France“. Politics \& Society 30 (3): 427-463.

Anheimer, H., Glasius, M., Kaldor, M. 2001. „Introducing Global Civil Society“. In H. Anheimer, M. Glasius, M. Kaldor (eds.) Global Civil Society 2001. Oxford: Oxford University Press, 2001, s. 3-22.

Arendtová, H. 1996. Původ totalitarismu. Praha: Oikoymenh.

Barry, B. 1999. „Statism and Nationalism: Cosmopolitan Critique“. In I. Shapiro, L. Brilmayer (eds.) Global Justice. New York and London: New York University Press, s. 12-66.

Barša, P. 2003. Hodina impéria. Zdroje současné zahraniční politiky USA. Brno: Mezinárodní politologický ústav. 
Barša, P., Císař, O. 2004. Levice v postrevoluční době. Občanská společnost a nová sociální hnutí v radikálni politické teorii 20. století. Brno: CDK.

Bennett, L. 2005. „Social Movements beyond Borders: Understanding Two Eras of Transnational Activism“. In D. della Porta, S. Tarrow (eds.) Transnational Protest and Global Activism. Lanham, Boulder, New York, Oxford: Rowman and Littlefield Publishers, s. 203-226.

Brecher, J., Costello, T., Smith, B. 2000. Globalization from Below. The Power of Solidarity. Cambridge, Massachusetts: South End Press.

Carothers, T. 1999. Aiding Democracy Abroad: The Learning Curve. Washington, D.C.: Carnegie Endowment for International Peace.

Castells, M. 1996. The Rise of the Network Society. Malden and Oxford, Blackwell.

Chandhoke, N. 2002. „The Limits of Global Civil Society“. In M. Glasius, M. Kaldor, H. Anheimer (eds.) Global Civil Society 2002. Oxford: Oxford University Press, s. 35-53.

Císař, O. 2003a. „Občanský republikanismus a deliberativní demokracie“. In V. Hloušek, L. Kopeček (eds.) Demokracie. Teorie, modely, osobnosti, podmínky, nepřátelé a perspektivy demokracie. Brno: Mezinárodní politologický ústav, s. 84-108.

Císař, O. 2003b. „Teorie demokracie na úsvitu globálního věku?“ In V. Hloušek, L. Kopeček (eds.) Demokracie. Teorie, modely, osobnosti, podmínky, neprátelé a perspektivy demokracie. Brno: Mezinárodní politologický ústav, s. 349-375.

Císař, O. 2003c. „Vzniká globální občanská společnost? Nestátní aktéři ve světové politice“. Mezinárodní vztahy 38 (4): 5-23.

Císař, O. 2004. Transnacionální politické sítě. Jak mezinárodní instituce ovlivňuji činnost nevládních organizací. Brno: Mezinárodní politologický ústav.

Císař, O. 2005. „Filosofické základy studia politického pluralismu“. Politologický časopis, 12 (2): 201-212.

Císař, O., Fiala, P. 2004. „Obhajoba zájmů a transnacionální vztahy: Úvod do studia“. In O. Císař, P. Fiala (eds.) Obhajoba zájmů a transnacionální vztahy. Brno: Mezinárodní politologický ústav, s. 9-26.

Clark, A. M. 2001. Diplomacy of Conscience. Amnesty International and Changing Human Rights Norms. Princeton and Oxford: Princeton University Press.

Connolly, W. 1991. „Democracy and Territoriality“. Millenium: Journal of International Studies, 20 (3): 463-484.

Cox, R. 1996. „Global Perestroika“. In R. Cox, T. Sinclair (eds.) Approaches to World Order. Cambridge: Cambridge University Press, s. 296-313.

della Porta, D., Tarrow, S. (eds.) 2005. Transnational Protest and Global Activism. Lanham, Boulder, New York, Oxford: Rowman and Littlefield Publishers.

Dryzek, J. S. 1999. „Transnational Democracy“. Journal of Political Philosophy, 7 (1): 30-51.

Evans, P. 2000. „Fighting Marginalization with Transnational Networks: Counter-Hegemonic Globalization“. Contemporary Sociology 29 (1): 230-241.

Florini, A. (ed.) 2000. The Third Force. The Rise of Transnational Civil Society. Washington, Tokyo: Carnegie Endowment, Japan Center for International Exchange.

Galtung, F. 2000. „A Global Network to Curb Corruption: The Experience of Transparency International“". In A. M. Florini (ed.) The Third Force: The Rise of Transnational Civil 
Society. Tokyo, Washington: Japan Center for International Exchange and Carnegie Endowment for International Peace, s. 17-47.

Gill, S. 1995. „Globalisation, Market Civilization, and Disciplinary Neoliberalism“. Millenium: Journal of International Studies, 24 (3): 399-423.

Glasius, M. 2002. „Expertise in the Cause of Justice: Global Civil Society Influence on the Statute for an International Criminal Court". In M. Glasius, M. Kaldor, H. Anheimer (eds.) Global Civil Society 2002. Oxford: Oxford University Press, 2002, s. 137-168.

Graeber, D. 2002. „The New Anarchists.“ New Left Review (13): 61-73.

Granowetter, M. 1973. „The Strength of Weak Ties.“ American Journal of Sociology, 78 (6): 1360-1380.

Greenwood, J. 2003. Interest Representation in the European Union. London: Palgrave.

GCS. 2004. Global Civil Society Yearbook [online]. Dostupné z: http://www.lse.ac.uk/Depts/ global/Yearbook/yearbook.htm

Habermas, J. 1996. Between Facts and Norms. Contributions to a Discourse Theory of Law and Democracy. Cambridge, Mass.: The MIT Press.

Habermas, J. 1998a. „Die postnationale Konstellation und die Zukunft der Demokratie“. In Die postnationale Konstellation. Politische Essays. Frankfurt am Main: Suhrkamp, s. $91-169$.

Habermas, J. 1998b. „The European Nation-State: On the Past and Future of Sovereignty and Citizenship“. In C. Cronin, P. De Greiff (eds.) The Inclusion of the Other. Studies in Political Theory. Cambridge, Oxford: Polity Press, Blackwell Publishers Ltd., s. 105-127.

Habermas, J. 1998c. „Does Europe Need a Constitution? Response to Dieter Grimm“. In C. Cronin, P. De Greiff (eds.) The Inclusion of the Other. Studies in Political Theory. Cambridge, Oxford: Polity Press, Blackwell Publishers Ltd., s. 155-161.

Habermas, J. 1998d. „Kant's Idea of Perpetual Peace: At Two Hundred Years' Historical Remove“. In C. Cronin, P. De Greiff (eds.) The Inclusion of the Other. Studies in Political Theory. Cambridge, Oxford: Polity Press, Blackwell Publishers Ltd., s. 165-201.

Habermas, J. 2001. „Why Europe Needs a Constitution“. New Left Review (11): 5-26.

Habermas, J. 2002. „Tři normativní modely demokracie“. In Teorie demokracie dnes. Praha: Filosofia, s. 79-95.

Habermas, J. 2004. „Státní občanství a národní identita“. Filosofický časopis, 52 (2): 185-205.

Habermas, J., Derrida J. 2003. „February 15, or What Binds Europeans Together: a Plea for a Common Foreign Policy, Beginning in the Core of Europe“. Constellations, 10 (3): 291-297.

Halliday, F. 2001. „The Romance of Non-state Actors“. In D. Josselin, W. Wallace (eds.) Non-state Actors in World Politics. New York: Palgrave, s. 21-37.

Hardt, M. 2002. „Today’s Bandung?“ New Left Review (14): 112-118.

Hardt, M., Negri, A. 2000. Empire. Cambridge, London: Harvard University Press.

Held, D. 1997. „Democracy and Globalization“. Global Governance, 3 (3): 251-267.

Held, D. 1999. „,The Transformation of Political Community: Rethinking Democracy in the Context of Globalization“. In I. Shapiro, C. Hacker-Cordón (eds.) Democracy's Edges. Cambridge: Cambridge University Press, s. 84-111. 
Held, D. 2000. „The Changing Contours of Political Community: Rethinking Democracy in the Context of Globalization“. In B. Holden (ed.) Global Democracy. Key Debates. London and New York: Routledge, s. 17-31.

Held, D. 2004. Global Covenant. The Social Democratic Alternative to the Washington Consensus. Cambridge, Malden: Polity.

Josselin, D., Wallace, W. (eds.) 2001. Non-state Actors in World Politics. New York: Palgrave.

Kagan, R. 2003. Of Paradise and Power. America and Europe in the New World Order. New York: Alfred A. Knopf.

Kaldor, M., Anheimer H., Glasius, M. 2003. „Global Civil Society in an Era of Regressive Globalization“. In M. Kaldor, H. Anheimer, M. Glasius (eds.) Global Civil Society 2003. Oxford: Oxford University Press, s. 3-33.

Keane, J. 2003. Global Civil Society? Cambridge: Cambridge University Press.

Keck, M., Sikkink, K. 1998. Activists Beyond Borders. Advocacy Networks in International Politics. Ithaca and London: Cornell University Press.

Keohane, R. 2002. „International Institutions: Can Interdependence Work?“ In Power and Governance in a Partially Globalized World. London and New York: Routledge, s. 27-38.

Keohane, R., Nye, J. 2000. „Introduction“. In J. Nye, J. Donahue (eds.) Governance in a Globalizing World. Cambridge, Mass., Washington D.C.: Visions of Governance for the 21 st Century, Brookings Institution Press, s. 1-41.

Keohane, R., Nye, J. 2001. Power and Interdependence, 3rd edition. New York: Longman.

Klein, N. 2001. „Reclaiming the Commons“. New Left Review (9): 81-89.

Kymlicka, W. 1999. „Citizenship in an Era of Globalization: Commentary on Held“. In I. Shapiro, C. Hacker-Cordón (eds.) Democracy's Edges. Cambridge: Cambridge University Press, s. 112-126.

Kymlicka, W. 2002. Contemporary Political Philosophy. An Introduction. 2nd edition. Oxford, New York: Oxford University Press.

Magnette, P. 2003. „European Governance and Civic Participation: Beyond Elitist Citizenship?“ Political Studies, 51: 144-160.

Marshall, T. H., Bottomore, T. B. 1992. Citizenship and Social Class. London and Concord: Pluto Press.

Mayall, J. 2000. „Democracy and International Society“. International Affairs, 76 (1): 61-75. McGrew, A. 2000. „Power Shift: From National Government to Global Governance?“ In D. Held (ed.) a Globalizing World? Culture, Economics, Politics. London and New York: Routledge and Open University, s. 127-166.

McGrew, A. 2002. „From Global Governance to Good Governance. Theories and Prospects of Democratizing the Global Polity." In M. Ougaard, R. Higgott (eds.) Towards a Global Polity. London and New York: Routledge, s. 207-226.

McMahon, P. 2001. „Building Civil Societies in East Central Europe: The Effects of American Non-governmental Organizations on Women's Groups“. Democratization, 8 (2): 45-68.

Mendelson, S., Glenn, J. (eds.) 2002. The Power and Limits of NGOs. New York: Columbia University Press.

Nye, J. S. 2001. „Globalization's Democratic Deficit. How to Make International Institutions More Accountable“. Foreign Affairs, 80 (4): 2-6. 
O’Brien, R., Goetz, A. M., Scholte, J. A., Williams, M. 2000. Contesting Global Governance. Multilateral Economic Institutions and Global Social Movements. Cambridge: Cambridge University Press.

Olson, M. 1970. The Logic of Collective Action. Public Goods and the Theory of Groups. New York: Schocken Books.

Oz-Salzberg, F. 2001. „Civil Society in the Scottish Enlightenment“. In S. Kaviraj, S. Khilnani (eds.) Civil Society. History and Possibilities. Cambridge: Cambridge University Press, s. $58-83$.

Pogge, T. 2002. World Poverty and Human Rights. Cambridge: Polity Press.

Polanyi, K. 1957. The Great Transformation. The Political and Economic Origins of Our Time. Boston: Beacon Press.

Risse-Kappen, T. (ed.) 1995. Bringing Transnational Relations Back In. Non-State Actors, Domestic Structures and International Institutions. Cambridge: Cambridge University Press.

Risse, T. 2003. „Transnational Actors in World Politics“. In W. Carlsnaes, T. Risse, B. A. Simmons (eds.) Handbook of International Relations. London: Sage Publications, s. 255-274.

Ruggie, J. G. 1994. „At Home Abroad, Abroad At Home: International Liberalization and Domestic Stability in the New World Economy“. Millennium: Journal of International Studies, 24 (3): 507-526.

Rucht, D. 2001. „Social Movements Challenging Neo-liberal Globalisation“. Central European Science Review, 2 (5): 94-114.

Scott, M. J. O. 2001. „Danger - Landmines! NGO-Government Collaboration in the Ottawa Process“،. In M. Edwards, J. Gaventa (eds.) Global Citizen Action. Boulder, Co.: Lynne Rienner, s. 121-133.

Shapiro, I. 2002. „Teorie demokracie: současný stav“. In Teorie demokracie dnes. Praha: Filosofia, s. 23-78.

Shapiro, I. 2003. Morální základy politiky. Praha: Karolinum.

Sikkink K., Smith, J. 2002. „Infrastructure for Change: Transnational Organizations, 1953-93“. In S. Khagram, J. V. Riker, K. Sikkink (eds.) Restructuring World Politics. Transnational Social Movements, Networks, and Norms. Minneapolis, London: University of Minnesota Press, s. 24-44.

Sklair, L. 1997. „Social Movements for Global Capitalism: the Transnational Capitalist Class in Action“. Review of International Political Economy, 4 (3): 514-538.

Tarrow, S. 1998. Power in Movement. Social Movements and Contentious Politics, 2 nd edition. Cambridge: Cambridge University Press.

Tarrow, S. 2000. Transnational Contention. Badia Fiesolana, San Domenico: EUI Working Paper RSC 2000/44.

Tarrow, S. 2001. „Transnational Politics: Contention and Institutions in International Politics“. Annual Review of Political Science, 4: 1-20.

Tarrow, S. 2002. „From Lumping to Splitting: Specifying Globalization and Resistance“. In J. Smith, H. Johnson (eds.) Globalization and Resistance. Transnational Dimensions of Social Movements. Lanham, Boulder, New York, Oxford: Rowman and Littlefield, s. 229-249. 
Thompson, D. F. 1999. „Democratic Theory and Global Society“. Journal of Political Philosophy, 7 (2): 111-125.

Tilly, Ch. 2004. Social Movements, 1768-2004. Boulder, London: Paradigm Publishers.

van Apeldoorn, B. 2000. „Transnational Class Agency and European Governance: The Case of the European Round Table of Industrialists“. New Political Economy, 5 (2): 157-181.

Velek, J. 2004. „Jürgen Habermas a utopie věčného míru. K legitimitě demokracie a globální spravedlnosti““. Filosofický časopis, 52 (2): 231-252.

Wade, R. 2002. „Bridging the Digital Divide: New Route to Development or New Form of Dependency?" Global Governance, 8: 443-446.

Walker, R. B. J. 1994. „Social Movements and World Politics“. Millenium: Journal of International Studies, 23 (3): 669-700.

Waltz, K. 1999. „Globalization and Governance“. Political Science and Politics, 32 (4): 693-700.

Wedel, J. 1998. Collision and Collusion. The Strange Case of Western Aid to Eastern Europe 1989-1998. New York: St. Martin's Press.

\section{Autor}

Ondřej Císař pracuje jako odborný asistent na katedře politologie Fakulty sociálních studií Masarykovy univerzity v Brně. Zabývá se politickou teorií, sociálními hnutími a dopady transnacionalizace na sociální hnutí a zájmové skupiny. Kontakt: cisar@fss.muni.cz 